University of Nebraska - Lincoln

DigitalCommons@University of Nebraska - Lincoln

1998

\title{
Estimating vegetation structural effects on carbon uptake using satellite data fusion and inverse modeling
}

\author{
Gregory P. Asner \\ University of Colorado \\ C. Ann Bateson \\ University of Colorado \\ Jeffrey L. Privette \\ NASA Goddard Space Flight Center \\ Nazmi El Saleous \\ NASA Goddard Space Flight Center \\ Carol A. Wessman \\ University of Colorado
}

Follow this and additional works at: https://digitalcommons.unl.edu/nasapub

Part of the Physical Sciences and Mathematics Commons

Asner, Gregory P.; Bateson, C. Ann; Privette, Jeffrey L.; El Saleous, Nazmi; and Wessman, Carol A., "Estimating vegetation structural effects on carbon uptake using satellite data fusion and inverse modeling" (1998). NASA Publications. 33.

https://digitalcommons.unl.edu/nasapub/33

This Article is brought to you for free and open access by the National Aeronautics and Space Administration at DigitalCommons@University of Nebraska - Lincoln. It has been accepted for inclusion in NASA Publications by an authorized administrator of DigitalCommons@University of Nebraska - Lincoln. 


\title{
Estimating vegetation structural effects on carbon uptake using satellite data fusion and inverse modeling
}

\author{
Gregory P. Asner, ${ }^{1}$ C. Ann Bateson, ${ }^{1}$ Jeffrey L. Privette, ${ }^{2}$ \\ Nazmi El Saleous, ${ }^{2,3}$ and Carol A. Wessman ${ }^{1}$
}

\begin{abstract}
Regional analyses of biogeochemical processes can benefit significantly from observational information on land cover, vegetation structure (e.g., leaf area index), and biophysical properties such as fractional PAR absorption. Few remote sensing efforts have provided a suite of plant attributes needed to link vegetation structure to ecosystem function at high spatial resolution. In arid and semiarid ecosystems (e.g., savannas), high spatial heterogeneity of land cover results in significant functional interaction between dominant vegetation types, requiring new approaches to resolve their structural characteristics for regional-scale biogeochemical research. We developed and tested a satellite data fusion and radiative transfer inverse modeling approach to deliver estimates of vegetation structure in a savanna region of Texas. Spectral mixture analysis of Landsat data provided verifiable estimates of woody plant, herbaceous, bare soil, and shade fractions at $28.5 \mathrm{~m}$ resolution. Using these subpixel cover fractions, a geometric-optical model was inverted to estimate overstory stand density and crown dimensions with reasonable accuracy. The Landsat cover estimates were then used to spectrally unmix the contribution of woody plant and herbaceous canopies to AVHRR multiangle reflectance data. These angular reflectances were used with radiative transfer model inversions to estimate canopy leaf area index (LAI). The suite of estimated canopy and landscape variables indicated distinct patterns in land cover and structural attributes related to land use. These variables were used to calculate diurnal PAR absorption and carbon uptake by woody and herbaceous canopies in contrasting land cover and land use types. We found that both LAI and the spatial distribution of vegetation structural types exert strong control on carbon fluxes and that intercanopy shading is an important factor controlling functional processes in spatially heterogeneous environments.
\end{abstract}

\section{Introduction}

Changes in land use often lead to changes in vegetation structure, which significantly impact biosphere-atmosphere exchange processes and biogeochemical cycles (e.g., carbon fluxes, nutrient dynamics). However, structural differences (e.g., type and amount of tissue) between vegetation types also predispose different ecosystems to distinct functional responses to human disturbance and climate variability [e.g., Townsend et al., 1996]. Vegetation structure is both an organizing force upon and a result of ecosystem function; structure exerts a set of constraints on the flow of carbon, water, and nutrients through ecosystems [Wessman and Asner, 1998]. At the same time, biogeochemical feedbacks and other processes constituting ecosystem function have a profound effect on structure [Shugart, 1997]. Because of the structural and functional dependence of ecosystems, regional analyses of vegetation change are needed to bridge the persisting gap between local and global-scale studies of climate change, land use impacts, and biogeochemical cycles [Walker, 1994].

\footnotetext{
${ }^{1}$ Cooperative Institute for Research in Environmental Sciences, University of Colorado, Boulder.

${ }^{2}$ NASA Goddard Space Flight Center, Greenbelt, Maryland.

${ }^{3}$ Department of Geography, Unıversity of Maryland, College Park.

Copyright 1998 by the American Geophysical Union.

Paper number $98 \mathrm{JD} 02459$.

$0148-0227 / 98 / 98 J D-2459 \$ 09.00$
}

To analyze actual rather than potential ecosystem function at regional scales, especially under conditions of changing land use, observations of changing vegetation structure must be linked to functional processes. To date, our ability to connect function to structure has been limited because (1) the physiological and biogeochemical links between structure and function are highly complex and (2) observation of structure is often constrained to detailed ground studies over very small scales (e.g., meters). Studies focusing on structure at large scales (e.g., kilometers) often lack sufficient detail required for many analyses of ecosystem function. Regional analyses of ecosystem function can thus benefit from extensive measurements of vegetation change at high spatial and "structural" resolution.

Arid and semiarid ecosystems (e.g., savannas, shrublands, and grasslands) cover about $40 \%\left(>53\right.$ million $\left.\mathrm{km}^{2}\right)$ of the Earth's terrestrial surface [Matthews, 1983] and can be found on all continents. These ecosystems are subjected to high landuse pressures, including intensive grazing, altered fire regimes, and clearing for agriculture [Crutzen and Andreae, 1990; Archer, 1994]. Land use often leads to changes in the structural attributes of vegetation types which, in turn, have significant impacts on ecosystem function in these regions [Tothill and Mott, 1985]. In savanna ecosystems, temporal and spatial variation in the relative abundance of woody plants and herbaceous species impacts patterns of carbon fixation, respiration, nutrient cycling and trace gas emissions to the atmosphere [e.g., Belsky et al., 1989; Carreira et al., 1994; Kauffman et al., 
1994]. Because of their high structural heterogeneity, significant functional interaction between vegetation types occurs in savanna ecosystems [Knoop and Walker, 1985; Scholes and Archer, 1997]. Theory and methods for resolving this structural heterogeneity as well as intercanopy functional effects are thus needed to improve estimates of arid and semiarid ecosystem processes under natural and human disturbance regimes.

Remote sensing is used in support of efforts to understand biogeochemical cycles and biosphere-atmosphere interactions at large scales [e.g., Field et al., 1995; Randerson et al., 1997; Sellers et al., 1997]. The primary factors influencing an optical remote sensing measurement of vegetation include canopy extent, leaf area index (LAI), shading, tissue optical properties, tissue angle distributions, and soil reflectance [Ross, 1981; Myneni et al., 1989]. A means to interpret this multivariate reflectance signal is required to access the vegetation characteristics of maximum interest. Many efforts have focused on statistical relationships between vegetation indices, such as the normalized difference vegetation index (NDVI), and plant attributes, including the fraction of absorbed photosynthetically active radiation (fAPAR), LAI, stomatal conductance, and phenology [e.g., Running et al., 1986; Gamon et al., 1995; Tieszen et al., 1997]. While the NDVI follows general trends in these variables, it can be inadequate for quantifying plant attributes at high spatial resolution due to vegetation-dependent relationships between NDVI and structural variables, soil background interference, anisotropic surface reflectance, and other factors [e.g., Baret and Guyot, 1991; Asrar et al., 1992; Goward and Huemmrich, 1992]. Vegetation indices have been particularly problematic in arid and semiarid ecosystems such as savannas and shrublands [Huete, 1988; van Leeuwen and Huete, 1996].

Radiative transfer (RT) model inversions are a promising approach for deconvolving the reflectance signal to estimate vegetation characteristics of interest. Surface reflectance is both highly anisotropic (non-Lambertian) and wavelength dependent [Gerstl, 1990]. Canopy RT models simulate the angular and spectral dependence of surface reflectance by simulating the interaction of photons with plant tissues and soil:

$R(\lambda)=f\left(\right.$ GEOM, LANDSTR, CANSTR $_{l}$, TISSUES $\left._{l}\right)$

where

$$
\begin{aligned}
& \mathrm{GEOM}=\left(\theta_{\text {sun }}, \theta_{\text {view }}, \phi_{\text {sun }}, \phi_{\text {view }}, \mathrm{IFOV}\right) \\
& \text { LANDSTR }=\left(\text { VEG }_{l}, \rho_{\text {soll }}(\lambda)\right) \\
& \text { CANSTR }_{l}=\left(\text { LAI, LAD, } \mathrm{H}_{\text {leaf }}\right)_{l} \\
& \text { TISSUES }_{l}=\left(\rho_{\text {leaf }}(\lambda), \tau_{\text {leaf }}(\lambda)_{l}\right.
\end{aligned}
$$$$
l=1, \cdots, \text { number of vegetation types }
$$

$R(\lambda)$ is the surface reflectance at wavelength $\lambda$. GEOM includes the Sun-sensor orientation $\left(\theta_{\text {sun }}, \phi_{\text {sun }}, \theta_{\text {view }}, \phi_{\text {view }}\right)$ and the sensor instantaneous field of view (IFOV). Landscape structure (LANDSTR) is represented by the horizontal distribution of distinct vegetation types $\left(\mathrm{VEG}_{l}\right)$ and the extent and optical characteristics $\left(\rho_{\text {sol }}(\lambda)\right)$ of bare soil. Canopy structure (CANSTR ${ }_{l}$ ) includes variables specifying the amount and orientation of plant tissues within each vegetation type $(l)$ : Leaf area index (LAI) is the total foliage area per unit ground area $\left(\mathrm{m}^{2} \mathrm{~m}^{-2}\right)$; leaf angle distribution (LAD) describes foliage ori- entation; a tissue hotspot parameter ( $H_{\text {leaf }}$ ) allows for the treatment of canopy self-shading [Myneni et al., 1989; Kuusk, 1991]. Leaf reflectance $\left(\rho_{\text {leaf }}(\lambda)\right)$ and transmittance $\left(\tau_{\text {leaf }}(\lambda)\right)$ properties define the optical characteristics of the photosynthetic TISSUES for each vegetation type $(l)$.

Numerical inversion of canopy RT models has proven to be a reasonable approach for decomposing the angular and spectral reflectance signal to estimate various canopy attributes [e.g., Goel and Thompson, 1984; Privette et al., 1994, 1996; Braswell et al., 1996]. The inversion is achieved by fitting, via an optimization routine, spectral reflectance measurements acquired under different Sun-sensor geometric conditions to modeled values. The model parameters minimizing the squared difference between the simulated and the actual reflectance values (e.g., that produce the best fit) are considered the retrieved canopy attributes [Asner et al., 1998a]. Inverse methods are advantageous because they eliminate the need for vegetation-specific statistical relationships between reflectance and biophysical parameters, and they explicitly account for the angular dependence of reflectance resulting from changes in Sun-sensor geometry. A major limitation to inverse modeling lies in acquiring an adequate number of angularly and/or spectrally unique observations to execute a stable, accurate model inversion [Goel, 1988]. Recently, Braswell et al. [1996] and Asner et al. [1998c] demonstrated constraints between leaf optical properties in different spectral bands, thus increasing the ratio of observations to free parameters and increasing the stability of inversions.

However, RT model inversions or any remote sensing approach is also complicated by horizontal mixing of distinct vegetation types within image pixels. The NOAA AVHRR, and the forthcoming EOS MODIS and MISR sensors, are the few spaceborne instruments capable of sampling the angular reflectance variation to employ RT model inversions [Barnsley et al., 1994]; yet, multiple vegetation structural types occur within their relatively large pixels $(1.1-4.3 \mathrm{~km})$. Mixed-pixel estimates of LAI or fAPAR and related variables such as NPP are difficult to interpret if the relative proportion of constituent vegetation structural types is unknown. Mixed-pixel ecological variables are effective parameters that do not necessarily represent the actual characteristics of vegetation units (e.g., trees, shrubs, grasses), making them difficult to validate on the ground. Therefore analysis of the relative contribution of distinct vegetation types to satellite reflectance data may improve canopy-level structural estimates.

In this paper, we report on an effort to combine spectral and angular reflectance data from multiple satellite sensors and to estimate a suite of vegetation structural attributes in spatially complex regions (e.g., savannas). We first evaluated a spectral unmixing/geometric-optical method for deriving subpixel AVHRR angular reflectances and for providing estimates of canopy extent, stand density, and crown dimensions of two dominant savanna vegetation types: woody and herbaceous plants. LAI of each vegetation type was then estimated using the unmixed angular reflectance data and canopy RT model inversions. Following the remote sensing analysis, we used the suite of estimated parameters to explore how vertical and horizontal variation in plant structure, and in particular intercanopy shading, affects carbon (C) uptake by constituent vegetation types, a functional attribute needed for large-scale analyses of terrestrial biogeochemical processes. 


\section{Methods}

\subsection{Regional Description}

The study focused on a $3515 \mathrm{~km}^{2}$ region of north Texas where the dominant ecosystems are mesquite (Prosopis glandulosa, a woody legume) savannas and grasslands which give way to intermittent riparian zones with deciduous woody plant communities (Figure 1). There are also five large lakes and many small water bodies scattered throughout the region. The dominant forms of land use are cattle ranching and agriculture.

The 200,000 ha Waggoner Ranch $\left(33^{\circ} 53^{\prime} \mathrm{N}, 99^{\circ} 3^{\prime} \mathrm{W}\right)$ is located between the four large lakes shown in Figure 1, south of Vernon, Texas. As on many ranches in Texas, intensive grazing and fire suppression have resulted in Prosopis encroachment upon former grasslands in the last 100 years [Archer, 1994], leading to a savanna physiognomy with scattered, discrete tree crowns embedded in a herbaceous layer dominated by grasses. There are three dominant landscape types associated with distinct differences in soil texture: (1) clay loams support productive savanna vegetation (Prosopis trees, grasses, forbs); (2) shallow clays have significantly less woody vegetation, light-tomoderate grass cover and large areas of bare soil; and (3) loamy bottomlands are indicative of riparian zones with larger temperate deciduous trees. Mean annual precipitation is 640 $\mathrm{mm}$, and mean monthly minimum and maximum temperatures are $-1.7^{\circ} \mathrm{C}$ (January) and $35.8^{\circ} \mathrm{C}$ (July), respectively.

\subsection{Remote Sensing Data}

Landsat thematic mapper (TM) data were acquired over the North Texas region in September 1992. This instrument measures surface radiance in six optical channels (centered at 480 , $560,660,830,1650$, and $2210 \mathrm{~nm}$ ) with a pixel resolution of $28.5 \mathrm{~m}\left(812 \mathrm{~m}^{2}\right)$. September was selected because it was one of the few times of the year when the tree canopy was green, while the herbaceous layer was dominated by senescent tissues. This strategic sampling provided the best spectral contrast for measuring the spatial extent of the two plant groups. Landsat data from April, August, and November 1992 were also considered, but none showed so strong a contrast between vegetation types as the September data. Each TM pixel was converted to exoatmospheric reflectance using prelaunch gains and offsets; estimates of apparent surface reflectance were achieved via dark object subtraction [Richards, 1993].

AVHRR data were collected between July 1 and 10, 1992, when both woody plant and herbaceous canopies were green and roughly at peak biomass for the season. Because of its large swath width $(>2300 \mathrm{~km})$ and often twice daily coverage, the AVHRR imaged the surface with different viewing and solar geometries over the 10 day period. Thirteen images were collected with view and solar zenith angles ranging from $2^{\circ}-68^{\circ}$ to $23^{\circ}-50^{\circ}$, respectively. Relative azimuth angles (between view and solar directions) ranged from $1^{\circ}$ to $5^{\circ}$ (six images in forward scattering direction) and $-176^{\circ}$ to $-180^{\circ}$ (seven backscattering images), indicating that the reflectance samples were acquired close to the solar principal plane [Barnsley et al., 1994].

The 13 AVHRR images were radiometrically and atmospherically corrected, geolocated, and screened for clouds. Radiometric calibration of visible (VIS) and near-infrared (NIR) channels was achieved using in-flight calibration coefficients [Vermote and Kaufman, 1995]. Dark current values were determined from deep space measurements performed by the instrument. The data were converted to apparent surface re-

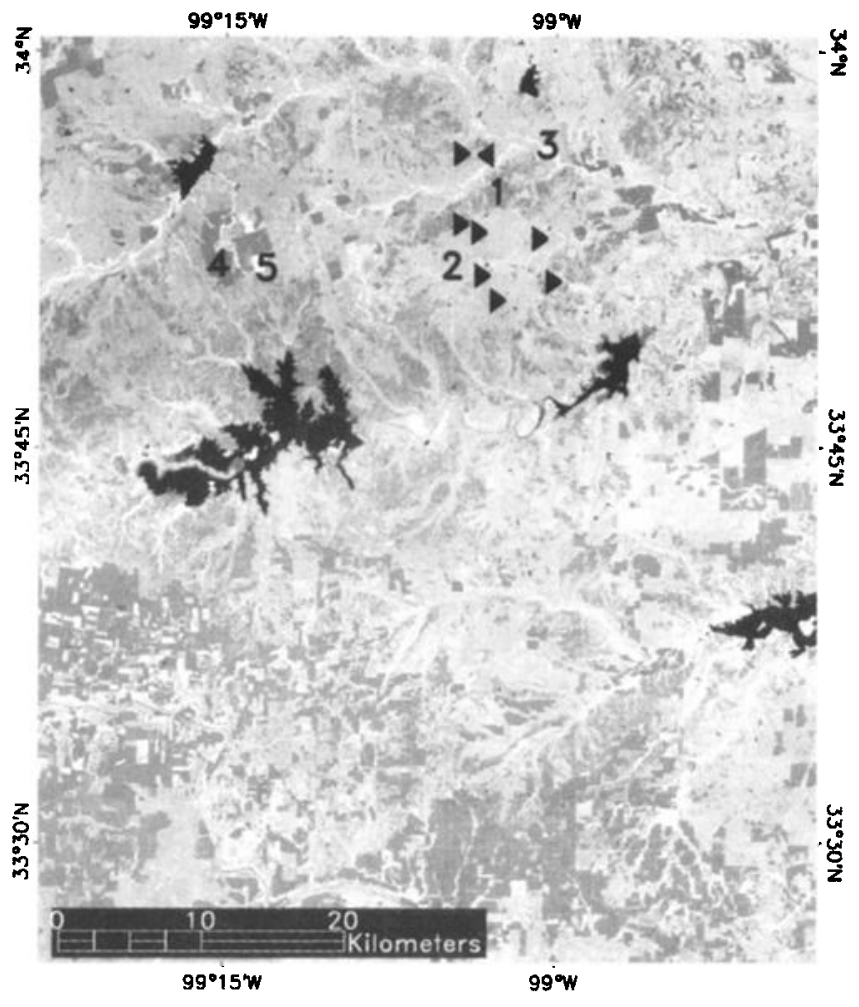

Figure 1. NDVI image of North Texas savanna region. A diverse array of land cover and land use types are present: (1) savannas on shallow clay soils, (2) savannas on clay loam soils, (3) riparian woodlands, (4) dormant (cleared) agricultural lands, and (5) active agricultural fields. The 200,000 ha Waggoner Ranch is located between the four large lakes; $60 \times 60 \mathrm{~m}$ plots were established on the savanna portion of the ranch (black triangles), where repeated measurements of tissue optical and canopy structural properties were made in 1996 and 1997.

flectance using an atmospheric radiative transfer model that accounts for water vapor, ozone, and Rayleigh scattering [Vermote et al., 1994]. The images were geolocated using satellite ephemeris data and a method to precisely determine spacecraft position [Rosborough et al., 1994; Baldwin and Emery, 1995]. Cloud screening was achieved using the Stowe [1991] method. Cloud shadow detection was accomplished using the cloud mask and spherical trigonometric calculations derived from Sun and sensor positions. To safeguard against reflectance values most likely affected by aerosols, we ignored measurements collected in the far forward scattering direction $\left(>45^{\circ}\right.$ view zenith angle), as these viewing geometries are most prone to atmospheric contamination [Tanre et al., 1992].

\subsection{Spectral Mixture/Geometric-Optical Analysis}

A spectral mixture/geometric-optical (G-O) analysis was used to access the angular reflectances of woody plants (overstory) and herbaceous (understory) vegetation within AVHRR pixels. The method, previously tested with simulated data [Asner et al., 1997], was used to produce the reflectance samples via three major steps: (1) high-resolution spectral unmixing of Landsat TM data; (2) G-O inverse modeling for overstory crown dimensions and spacing, and for TM-AVHRR shadow correction; and (3) low-resolution AVHRR spectral unmixing. The first step employed the approach of Bateson and Curtiss 
Table 1. Summary of Canopy Radiative Transfer Model Parameters and Constraints During Model Inversions

\begin{tabular}{|c|c|c|}
\hline Model Parameter & Constraint in Inversion & Source \\
\hline Leaf area index & none & $\cdots$ \\
\hline \multicolumn{3}{|l|}{ Leaf angle distribution } \\
\hline woody plants & plagiophile* & field measurements $\dagger$ \\
\hline herbaceous canopy & erectophile* & field measurements $\dagger$ \\
\hline Tissue optical properties & constrained and linked to NIR reflectance & field measurements $\dagger$ \\
\hline Tissue hotspot parameter & fixed & Privette et al. [1996] \\
\hline Soil reflectance & VIS reflectance linked to NIR reflectance & field measurements \\
\hline Solar geometry & variable & AVHRR ephemeris data \\
\hline Viewing geometry & variable & AVHRR ephemeris data \\
\hline
\end{tabular}

* See text for explanation.

†See Asner et al. [1998b, c].

[1996] but with a recently developed method for automatically deriving cover reflectances using simulated annealing techniques. The method has already been successfully tested in other semiarid ecosystems, including grasslands and savannas [Wessman et al., 1997; Bateson et al., 1998]. This first step provided estimates of woody plant and herbaceous covers, bare soil, water, and shade within TM pixels.

Inconsistent shade fractions caused by the differences in Landsat and AVHRR sensor and solar geometries were corrected using a crown G-O model [Li and Strahler, 1985, 1992]. This model produces sunlit overstory, sunlit understory, and shaded understory fractions from overstory crown dimensions, stand density (density of crowns per pixel area), and Sunsensor geometry. The model was inverted using the Landsatderived tree (overstory), herbaceous plus soil (sunlit understory), and shade understory fractions (from step 1) to estimate tree crown dimension ratios and stand density. The inversion was achieved using a quasi-Newton optimization algorithm (E04JAF, NAG Ltd.) which minimized the difference between measured and modeled cover fractions. Forward modeling with the estimated G-O parameters, but with the Sun-sensor geometry of each AVHRR pixel, provided corrected understory shade and sunlit cover fractions. Finally, the AVHRR data were spectrally unmixed using these shade-corrected Landsat cover fractions [Asner et al., 1997], providing angular overstory and understory canopy reflectances.

During the spectral mixture/G-O analysis, there were several points at which the procedure was evaluated. First, tree cover estimates from aerial photographs were used to evaluate the accuracy of the Landsat spectral unmixing (from step 1). Second, stand density and crown dimension ratio estimates (from step 2) were evaluated against field measurements. Third, forward integration of the G-O model produced new overstory and understory fractions. Asner et al. [1997] noted that the overstory fraction should not change significantly during the shadow correction (inverse-to-forward modeling) process, providing a final check on the stability of the method.

\subsection{Radiative Transfer Model Inversions}

To estimate the LAI of overstory and understory canopies, we inverted a discrete ordinates radiative transfer model (DISORD) [Shultis and Myneni, 1988] using the angular reflectances derived from the AVHRR spectral unmixing. In the forward mode, DISORD produces top-of-canopy reflectance values from LAI, LAD, leaf optical properties, soil reflectance, Sun-sensor orientation, and leaf hotspot parameters (equation (1)). Model inversion was achieved using the same minimiza- tion algorithm employed in the G-O model inversions. To ensure that a global minimum was reached in each inversion, three restarts of the routine were executed by adding random values to the retrieved parameters from each previous minimization attempt [Privette et al., 1996]. The value representing the minimum of all attempts was retained, and the model parameters producing this minimum were considered the retrieved surface variables.

Leaf optical properties and soil reflectance measurements, collected in 1996 and 1997, were used to constrain the RT model inversions. Asner et al. [1998c] showed that leaf optical data in AVHRR VIS and NIR channels could be linked, so fewer tissue parameters are required for the RT model inversions. A similar approach was used to relate soil reflectance in the two AVHRR channels. The RT model also requires a LAD parameter, describing how the tissues are inclined in the canopy [deWit, 1965; Myneni et al., 1989]. Field data on tissue angle distributions were used to constrain this parameter during the inversion. The canopy model parameters, constraints, and sources of information for those constraints are described in Table 1.

\subsection{Field Data and Aerial Photography}

Measurements of canopy dimensions, LAI, leaf angle distributions, leaf optical properties, and soil reflectance were collected in ten $60 \times 60 \mathrm{~m}$ savanna plots across the Waggoner Ranch in July 1996 and 1997 (Figure 1). Tree height (ground to crown center), crown radius (mean of long and perpendicular axes), and crown vertical radius of Prosopis trees were measured in each plot. These measurements were converted to dimension ratios describing the shape and height of a generalized ellipsoidal crown [Li and Strahler, 1985, 1992] (Figure 2). The $b: r$ ratio defines the dimensions of the crown, where $b$ and $r$ are the vertical and horizontal radii, respectively. The $h: b$ ratio defines the crown position relative to the height of the canopy ( $h$ is crown height from ground to crown center). These crown dimension ratios aided in the evaluation of the $\mathrm{G}-\mathrm{O}$ inverse modeling portion of the spectral unmixing process.

LAI of woody and herbaceous covers were estimated in July 1996 and 1997 using a plant canopy analyzer (Licor LAI-2000, Licor, Inc., Lincoln, Nebraska). Details of the sampling design were provided by Asner et al. [1998b]; the analyzer was calibrated against destructive harvest measurements, and a corrective equation was developed for woody plants found throughout the region. Leaf angle distributions were also quantified throughout the Waggoner Ranch plots using a leaf 

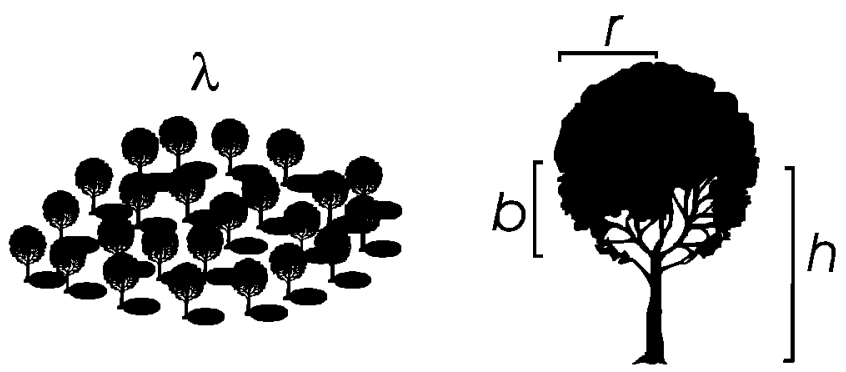

Figure 2. Shading between overstory and understory canopies can be derived from three variables describing the spacing and shape of ellipsoidal tree crowns. Assuming no overlap of the crowns, overstory stand density $(\lambda)$ describes the number of crowns per area. Dimension ratios $(b: r, h: b)$ describe the size and height of an ellipsoidal crown.

inclinometer, followed by conversion to inclination distribution functions [Norman and Campbell, 1989].

High spatial resolution $(\sim 0.25 \mathrm{~m})$ color-IR aerial photographs were collected over the savanna areas containing the $60 \times 60 \mathrm{~m}$ plots. Photographs were coregistered to the Landsat TM data using differentially corrected GPS. Tree cover and stand density were estimated in each plot and surrounding area using both manual interpretation and digital image-processing techniques.

\subsection{Modeling Carbon Uptake}

To evaluate the importance of canopy and landscape structural properties for ecosystem function, we used the suite of parameters derived from the remote sensing analysis to model daily total $\mathrm{AAPAR}$ and $\mathrm{C}$ uptake at the regional level. Instantaneous foliar-fAPAR, the fraction of incoming PAR $\left(\mathrm{PAR}_{t}\right)$ absorbed by photosynthetic plant tissues (green leaves), can be calculated using a RT model such as DISORD [Shultis and Myneni, 1988]. PAR, (given in $\mathrm{J} \mathrm{m}^{-2} \mathrm{~s}^{-1}$ ) depends upon solar zenith angle and sky conditions, while foliar-fAPAR is a function of the variables described in equation (1) [Goward and Huemmrich, 1992]. Daily total foliar-fAPAR $(\Psi)$ is the diurnally integrated fraction of PAR that is available for photosynthesis:

$$
\Psi=\frac{\int_{T} \operatorname{APAR}_{\text {follagc }}(t) d t}{\int_{T} \operatorname{PAR}_{\imath}(t) d t}=\frac{\int_{T} \operatorname{fAPAR}_{\text {fol lage }}(t) \cdot \operatorname{PAR}_{\imath}(t) d t}{\int_{T} \operatorname{PAR}_{t}(t) d t}
$$

where $\mathrm{APAR}_{\text {foliage }}$ is the amount of incoming PAR absorbed by the foliage at time $(t)$, and the integration occurs over the number of daylight hours. This approach to calculating daily total foliar-fAPAR is most accurate when the canopy is horizontally homogeneous. Where intercanopy shading is prominent, as in savanna ecosystems, this measure may be inadequate to characterize PAR absorption at landscape levels.

As solar zenith angle changes throughout a day, diurnal integration of foliar-fAPAR by the understory canopy requires that the shaded fraction be calculated. Similarly, individual overstory canopies intercept photons at different angles (with different path lengths involved) throughout a day, and this must be accounted for when scaling the functional properties of discrete crowns (Prosopis trees) to landscape and regional levels [Asner and Wessman, 1997]. The diurnally integrated amount of energy absorbed by overstory and understory covers can be calculated:

$$
E_{l}=\int_{T} K_{l}(t) \operatorname{fAPAR}_{\text {folage }}(l, t) \operatorname{PAR}_{l}(t) d t
$$

where $E_{l}$ is the amount of radiant energy (in $\mathrm{MJ} \mathrm{m} \mathrm{m}^{-2} \mathrm{~d}^{-1}$ ) absorbed by sunlit foliage in vegetation type $(l)$, and $K_{l}$ is the fraction of vegetation type $(l)$ which is sunlit at time $(t)$. In the PAR spectral region, a small percentage of incident radiation is transmitted through the overstory canopies onto the shaded understory (depending on oversiory LAI, êtc.). In this special case, the radiant energy absorbed by the shaded understory is modeled:

$E_{\text {shdde }}=\int_{T} K_{\text {shadc }}(t) \operatorname{fAPAR}_{\text {Iolage }}($ shade, $t) \operatorname{PAR}_{i}(t) d t$

where $K_{\text {shade }}$ is the areal fraction of shaded understory, and $P A R_{t}$ is the amount of incident radiation transmitted through the overstory canopy.

Assuming a light utilization efficiency factor $(\varepsilon)$ for each vegetation type (given in $\mathrm{g} C$ per MJ PAR), the net $C$ uptake by each sunlit and shaded vegetation type $(l)$ can be estimated on a daily, seasonal, or annual basis:

$$
C_{l}=\int_{T} K_{l}(t) \operatorname{fAPAR}_{\text {foliage }}(t) \operatorname{PAR}_{t}(t) \cdot \varepsilon_{l} d t
$$

Light utilization efficiency factors and fAPAR calculations have been used to determine spatial and temporal variation in NPP with changing vegetation types and leaf area (phenology) at global scales [e.g., Ruimy et al., 1994; Field et al., 1995]. Here we tested the importance of intercanopy shading and other landscape-level structural features on $\mathrm{C}$ uptake at regional scales. Using a three-dimensional geometric-optical/RT model [Li and Strahler, 1992; Myneni and Asrar, 1993] and equation (5), we simulated the diurnally integrated $\mathrm{C}$ uptake by woody plant and herbaceous vegetation types in a $32 \mathrm{~km}^{2}$ area of Waggoner Ranch. For solar inputs $\left(\mathrm{PAR}_{t}\right.$ ) we used the mean values of incident PAR measurements collected between July 3 and 9, 1996, at the site (Figure 3).

\section{Results and Discussion}

\subsection{Field Measurements}

Prosopis LAI values ranged from $0.7-1.9$ in 1996 to $1.8-3.4$ in 1997. Texas endured one of the driest years on record in 1996. Waggoner Ranch received only $297 \mathrm{~mm}$ from JanuaryJuly 1996, but $606 \mathrm{~mm}$ were received during the same period in 1997. The rainfall in 1997 was higher than the 22 year JanuaryJuly mean of $434 \mathrm{~mm}$. Therefore the 1996 and 1997 measurements probably bracketed the full range of wet and dry years. This is particularly important because Prosopis production is highly sensitive to rainfall in the first half of the growing season [Ansley et al., 1992]. The AVHRR data were collected in July 1992, a year in which January-July rainfall was recorded at 581 $\mathrm{mm}$ at Waggoner Ranch. Therefore Prosopis foliar production was likely to be relatively high in that year as well. Herbaceous LAI values ranged from 2.1 to 4.4 in 1996 and from 1.6 to 3.1 


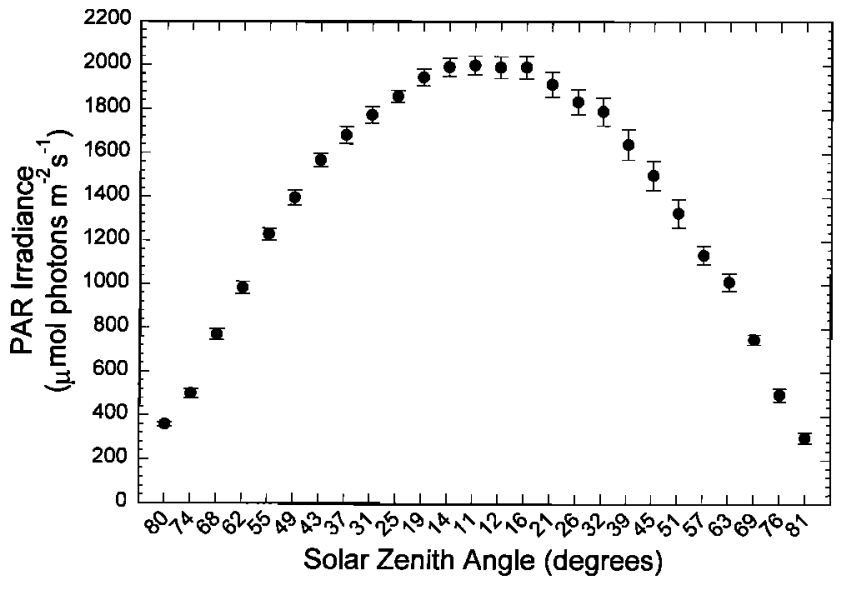

Figure 3. Incident PAR collected on Waggoner Ranch throughout a week in July 1997. Mean values were used in modeling regional PAR absorption and carbon uptake. Error bars $=1$ s.d.

in 1997. It is difficult to determine what caused the difference between years since grazing frequency/intensity and rainfall were involved.

Prosopis leaf angle distributions were similar during both measurement periods. Mean leaf angle ranged from $39^{\circ}-49^{\circ}$ in 1996 to $40^{\circ}-49^{\circ}$ in 1997 (same individuals), but upon transforming the data to distribution functions, all tended toward plagiophile (distributed about a mean value of $45^{\circ}$ ). Herbaceous leaf angles ranged from $49^{\circ}$ to $63^{\circ}$, similar to those of the Konza tallgrass prairie in Kansas [Privette et al., 1996]. Transformation of these data to distributions showed a tendency toward erectophile orientation.

The height of Prosopis trees ranged from 0.9 to $4.9 \mathrm{~m}$, with a mean $( \pm 1$ s.d.) $=3.3(0.8) \mathrm{m}$. Crown widths had a mean $( \pm 1$ s.d. $)=4.0(1.1) \mathrm{m}$. The ratio of crown vertical-tohorizontal radius $(b: r)$ ranged from 0.59 to 1.01 , with mean ( \pm 1 s.d.) $=0.85(0.15)$. The ratio of crown height (ground to crown center) to crown vertical radius $(h: b)$ was 1.2 (s.d. $=0.1$ ).

\subsection{Land Cover at Sub-28 Meters}

The Landsat spectral unmixing produced five subpixel covers: green canopies (dominated by trees in the September 1992 TM image), senescent canopies (dominated by herbaceous material), water, bare soil, and shade (Plate 1). On the Waggoner Ranch, tree cover was highest in the riparian zones (58-77\%), moderate on the clay loam savannas (31-53\%), and low on the shallow clay savannas (4-24\%). Herbaceous cover was high on the clay loam savannas (33-61\%), moderate on the shallow clay areas (12-27\%), and low in the riparian zones $(0-19 \%)$. Bare soil extent was highest $(27-44 \%)$ in the shallow clay savannas and lowest $(0-2 \%)$ in the riparian zones. The water cover fractions emphasized the small ponds on the ranch, while the shade fraction was high (19-26\%), moderate (16-20\%), and low $(9-13 \%)$ in the riparian, clay loam, and shallow clay areas, respectively. Throughout the region, the status of various croplands were also emphasized. Areas of active cropping had high green (52-100\%) and low bare soil (0-48\%) fractions, while dormant agricultural areas showed opposite patterns.

On Waggoner Ranch, tree cover fractions from the Landsat unmixing usually fell within 1 standard deviation of the tree cover estimates derived from aerial photography (Figure 4). Although the air photo estimates were probably more accu- rate, they incorporated error as well due to vignetting of the photography and digital interpretation errors. Nonetheless, the mean error between the methods was only $4 \%($ s.d. $=2 \%)$, well within the maximum allowable for the remainder of the unmixing process [Asner et al., 1997].

\subsection{Landscape Structure}

The G-O model inversions produced realistic estimates of stand density $(\lambda)$ and crown dimension ratios $(b: r, h: b)$. In the savanna areas, where Prosopis trees were dispersed throughout the landscape, $\lambda=0.02-0.12$ or about $16-97$ crowns per TM pixel (Figure 5). Air photo estimates of stand density within the savanna plots on Waggoner Ranch ranged from 59 to 87 crowns per TM pixel and agreed well with those derived from the G-O inverse modeling (means $=52-93$ crowns; Figure 6a). In riparian zones, where trees were taller and relatively tightly spaced, $\lambda=0.14-0.26$ which equates to roughly 113-211 crowns per pixel. Values for $\lambda$ were highest in active croplands $(\sim 1.0)$; however, conversion to crowns per pixel was not possible because $\lambda$ saturates due to constraints imposed upon the crown dimension ratios (see below) [ $\mathrm{Li}$ and Strahler, 1985, 1992]. Dormant agricultural areas produced values from 0.00 to 0.015 , indicating that a few plants were present. In general, $\lambda$ appeared to track differences in stand density quite well and produced reasonable values within the savanna areas of greatest interest to this study.

During the G-O model inversions, $b: r$ was constrained to a range of $0.3-1.8$ based on field measurements and literature sources [Asner et al., 1997], while $h: b$ was permitted to vary between 1.0 (the minimum possible) and 5.0 (height $=5 \times$ crown vertical radius). At the regional level, estimated tree $h: b$ ranged from 1.0 to 2.7 , while $b: r$ ranged from 0.3 to 1.3 (Figure 5). Among the savanna plots on Waggoner Ranch, retrieved values were often within 1 standard deviation of the field measurements (Figure $6 \mathrm{~b}$ and $6 \mathrm{c}$ ). Overall, the G-O model inversions appeared to provide better stand density estimates than crown dimension ratios. To some extent, this was expected since the method averaged the dimensions over many more tree crowns per TM pixel than were measured in the field. Stand density was evaluated using air photos, providing a more robust comparison to satellite-based estimates. Even given the field sampling of crown dimension ratios on different size trees in the savanna plots, it was difficult to fully evaluate the G-O inversion results due to the high spatial heterogeneity of tree crown sizes. Nonetheless, these validation efforts and a local knowledge of vegetation cover and structure on the ranch provided evidence that the method worked well within ecologically realistic limits.

\subsection{Intercanopy Shading}

Forward G-O modeling produced shadow-corrected Landsat cover fractions for each AVHRR Sun-sensor geometry (13 images). As mentioned earlier, the woody plant cover fractions should not change significantly from the original values (from Landsat unmixing) to those derived from the G-O inverse-toforward modeling process. Plate 2 shows the coefficients of variation (CV) for the overstory, sunlit understory, and shaded understory cover fractions resulting from changes in the AVHRR view and solar zenith angles. In the clay loam savanna areas, CVs ranged from $3-6 \%, 12-24 \%$, to $42-62 \%$ for overstory, sunlit understory, and shaded understory covers, respectively. The shallow clay savannas had somewhat similar values: $5-11 \%, 7-16 \%$, and $36-68 \%$ for overstory, sunlit un- 


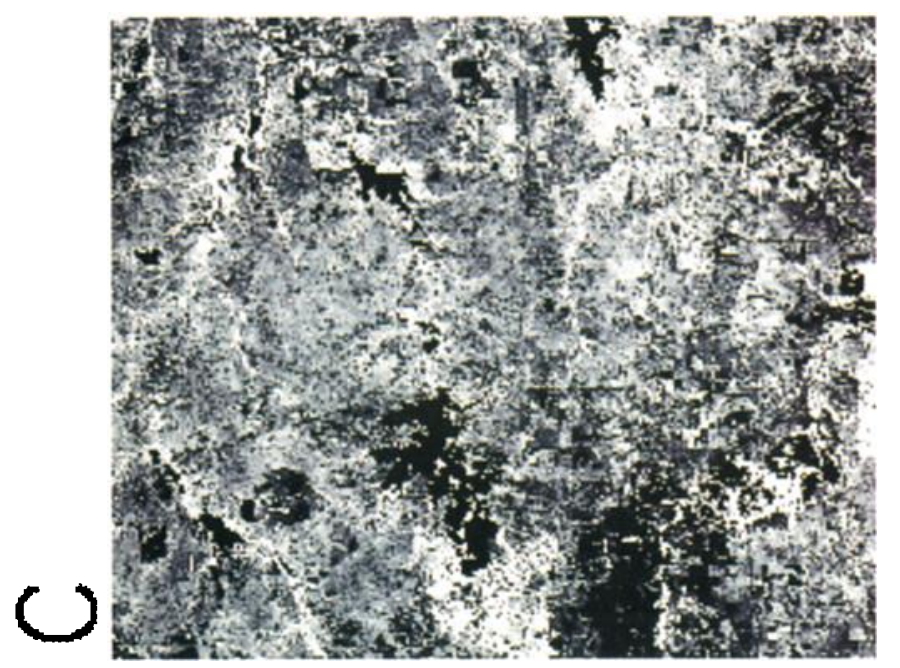

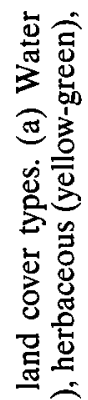

范

용

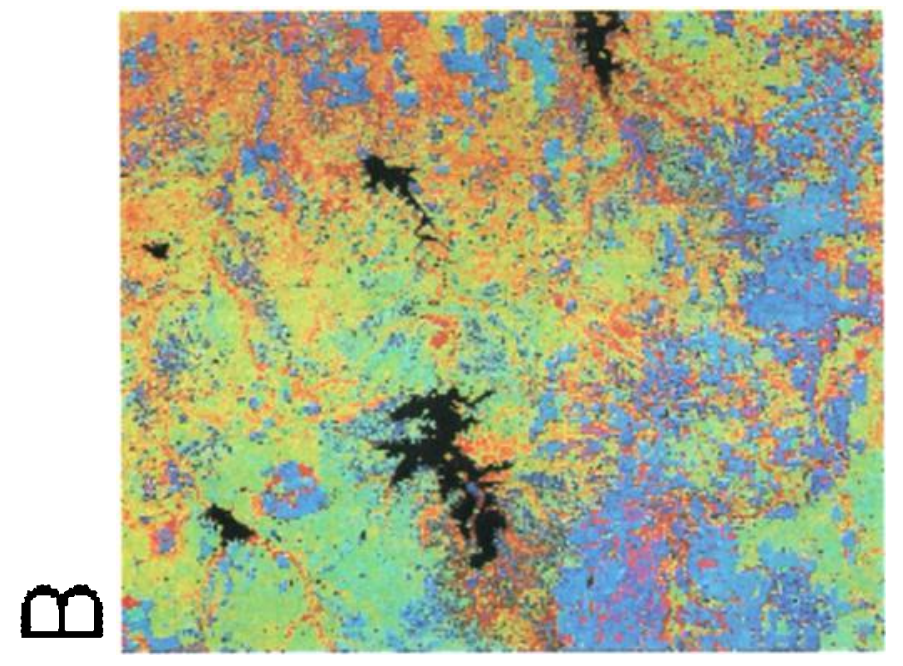

兽

艺

常 궁

के

몽음

递

형를

000

อ

离

폰

पु

की

它它

효

荡点焉

寻宁

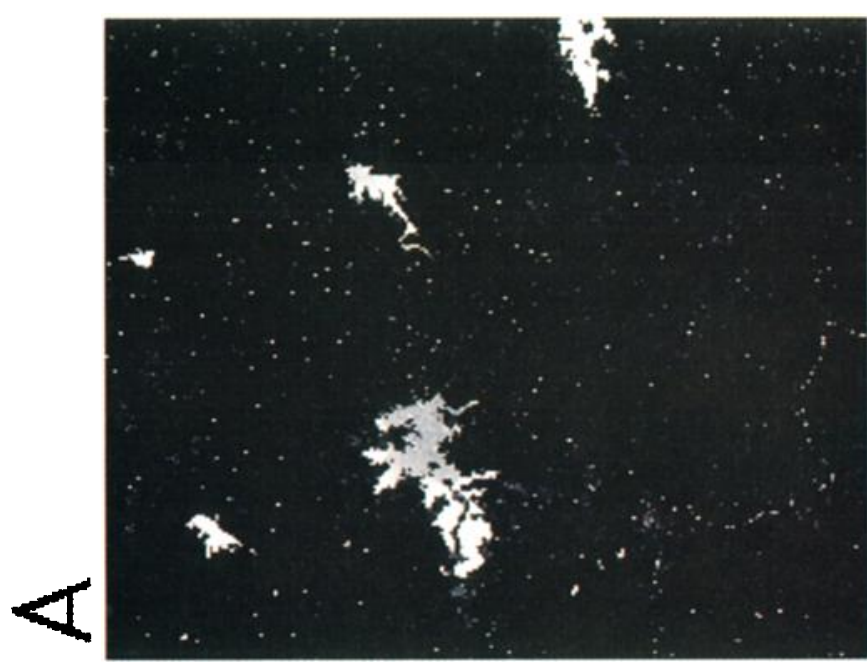

要

열

잉

可

형를

它

-

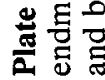




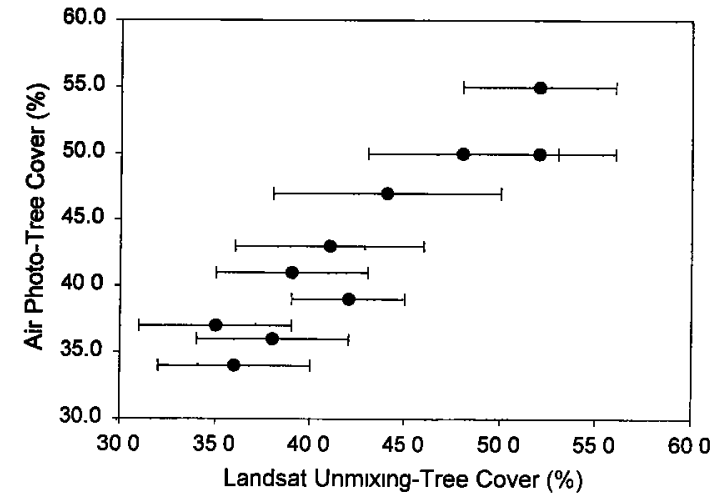

Figure 4. Comparison of woody plant cover fractions derived from Landsat TM spectral mixture analysis and aerial photography.

derstory, and shaded understory covers, respectively. In riparian areas, CVs were low for the overstory (2-7\%) but were high for the sunlit $(20-48 \%)$ and shaded (34-57\%) understory. Dormant agricultural fields had small shade CVs $(0-$ $11 \%$ ); the values were often nonzero, indicating the presence of some standing material (which caused shadow fraction changes) in the cleared fields. Active croplands had sunlit and shaded cover fractions that varied by $25-60 \%$ and $44-55 \%$, respectively.

These analyses suggest that observed shadows, which change significantly with solar and viewing geometry, can be quantified and accounted for using this spectral unmixing method. In fact, these results provide a unique spatially oriented, quantitative understanding of how solar and viewing geometry affect cover fraction estimates of contrasting vegetation types.

\subsection{Leaf Area Index}

The AVHRR spectral unmixing step produced angular reflectance samples of woody plant (overstory) and herbaceous (understory) covers at $4 \times 4 \mathrm{~km}$ resolution (Plate 3). A decrease in spatial resolution of the AVHRR data $(1-4 \mathrm{~km})$ occurred because the spatial homogeneity of vegetation covers within the savanna areas produced instability in the final equations used in AVHRR unmixing (explained in detail by Asner et al. [1997]). Stability in the method was restored by increasing the size of the unmixed subscenes to $4 \times 4$ AVHRR pixels $(16$ $\mathrm{km}^{2}$ ). For the entire region, overstory LAI estimates ranged from 0.0 to 5.8 , including the active agricultural areas. Savanna
A

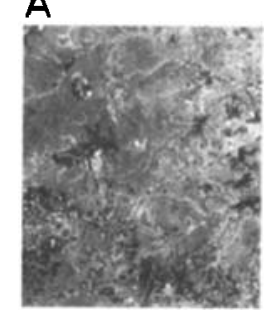

0.0
B

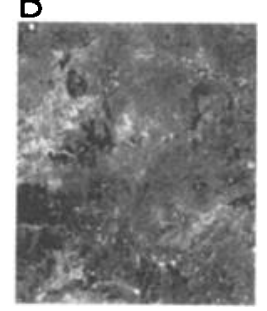

C

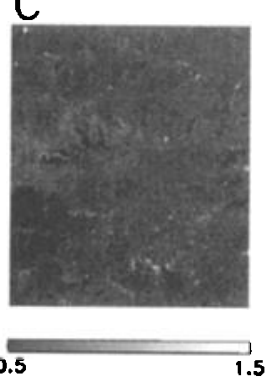

Figure 5. Regional heterogeneity of (a) overstory stand density $(\lambda)$, (b) ratio of crown height (ground to crown center) to crown vertical radius $(h: b)$, and (c) ratio of crown horizontal to vertical radius $(b: r)$. and woodland areas had overstory LAI values between 0.9 and 5.1 and herbaceous LAI from 0.2 to 3.7 (Table 2).

Remote sensing estimates of savanna tree and herbaceous canopy LAI were generally in agreement with field measurements (Figure 7a). Estimated tree LAI usually fell between the low and the high ranges acquired in the field during the dry (1996) and wet (1997) years. The evaluation is only proximate because the AVHRR estimates represent a mean for large areas $\left(16 \mathrm{~km}^{2}\right)$ in comparison to the field measurements $(360$ $\mathrm{m}^{2}$ ). However, the similarity between ground and inversion results suggests that LAI is relatively constant across the savanna. This is reasonable since $>95 \%$ of the tree canopy is comprised of the species Prosopis glandulosa (J. Ansley, personal communication, 1998). Estimates of herbaceous LAI were also in general agreement with field measurements (Figure $7 \mathrm{~b}$ ). The inverse modeling approach produced results that usually fell between minimum and maximum field LAI values but were often closer to the 1997 (wet year) data. Since 1992 was also a wet year, the results suggest a correspondence, although continued analysis of LAI over time is required to confirm any relationship.

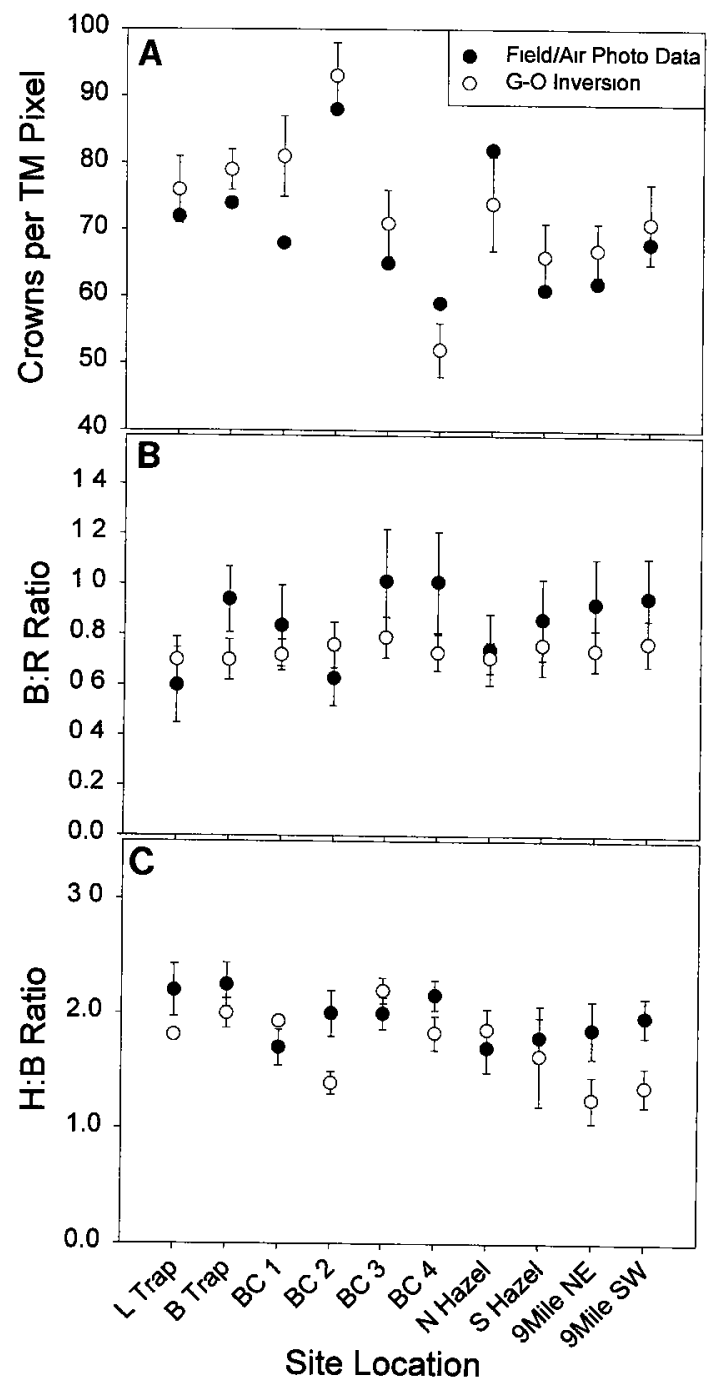

Figure 6. Site comparison of field/air photo and inverse modeling estimates of (a) overstory stand density $(\lambda)$, (b) crown dimension ratio $b: r$, and (c) crown dimension ratio $h: b$. Error bars $=1 \mathrm{~s} . \mathrm{d}$. 

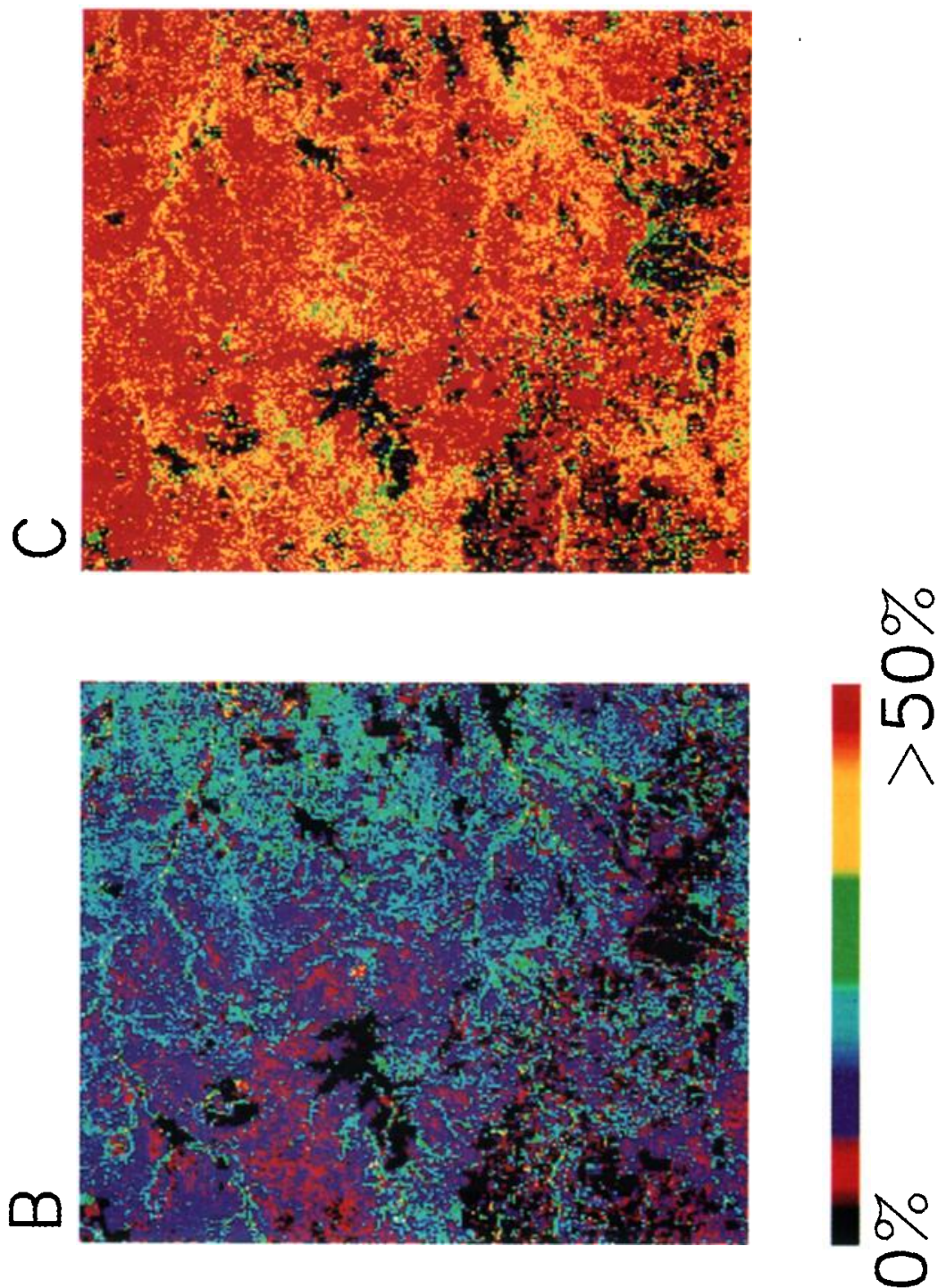

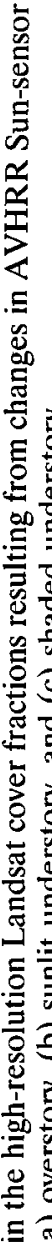

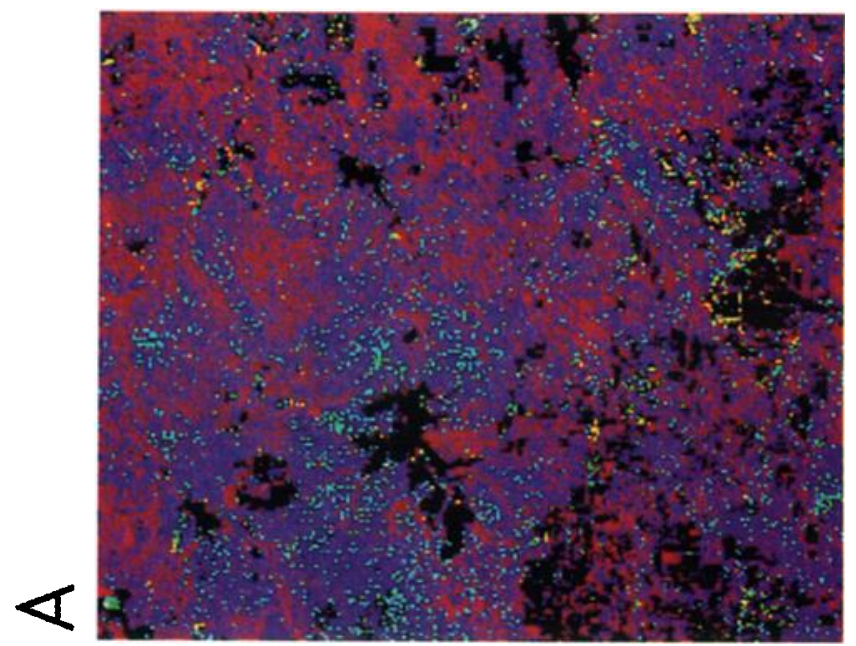

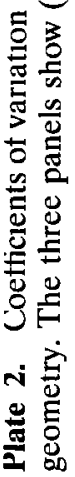




\section{$\mathbf{A}$}

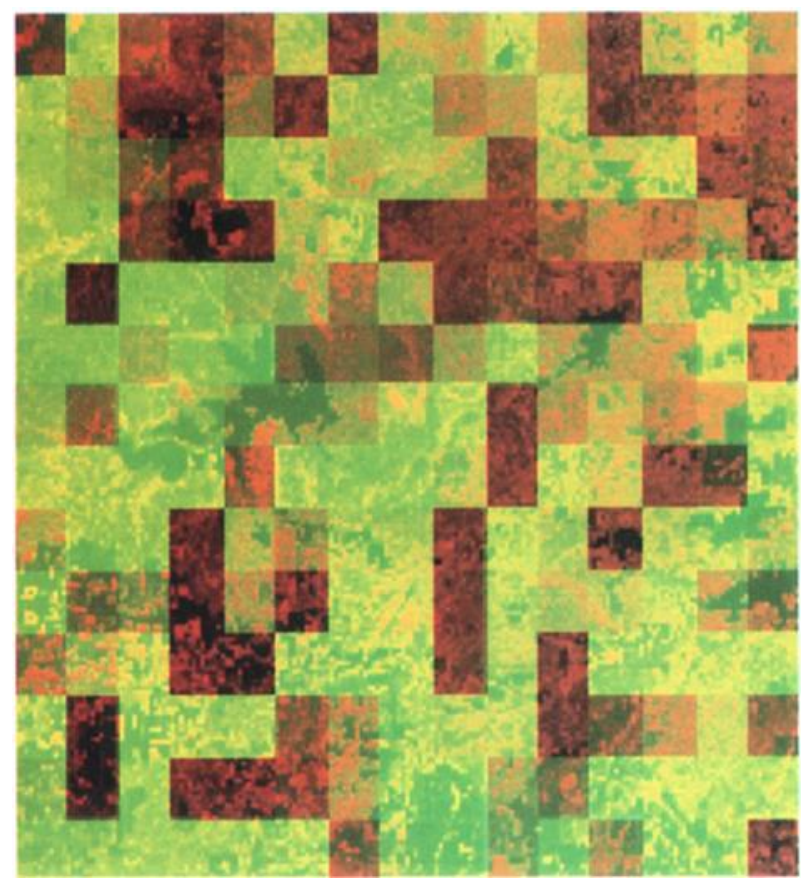

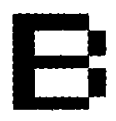

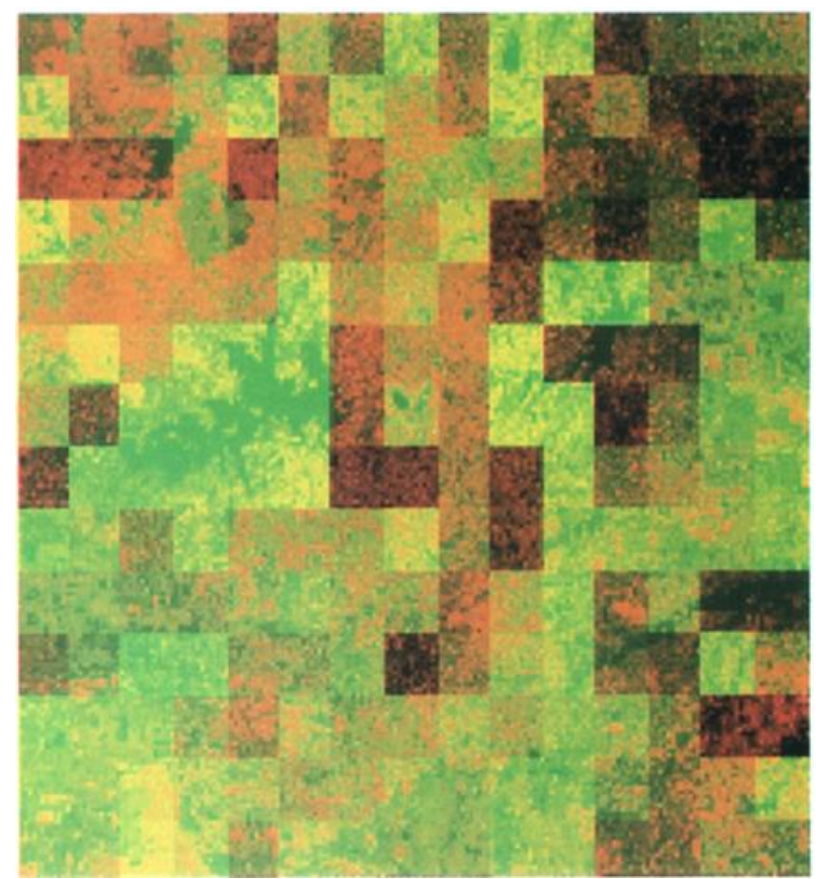

Plate 3. Regional estimates (at $4 \times 4$ AVHRR pixel resolution) of (a) overstory and (b) understory LAI from canopy RT model inversions. High LAI in dark shades of green, moderate LAI in orange/yellow, and low LAI in red. Background Landsat NDVI image is provided for spatial reference.

\subsection{Structural Heterogeneity of Land Cover and Land Use}

The suite of canopy and landscape attributes acquired through spectral mixture analysis and inverse modeling showed distinct patterns in the dominant land cover and land use features found in the region (Table 3). The two common savanna landscapes occur on sharply different soil types, leading to pronounced differences in the extent and structure of woody and herbaceous plants. Areas dominated by clay loam soils have historically supported high grazing pressures due to relatively higher grass production [Heitschmidt et al., 1986; J. Ansley, pers. communication, 1998). This, in combination with fire suppression (due to both fire management and removal of herbaceous biomass by cattle), has led to significant increases in the presence of woody plants (primarily Prosopis glandulosa) during the past century [Archer, 1994]. The retrieved variables indicated that the clay loam savannas had significantly higher tree cover and LAI than the shallow clay savannas. Since grass production tends to be lower (on a per area basis) on the shallow clays, less grazing tends to occur in these areas [Heitschmidt et al., 1982, 1987]. This correlation has also been observed in other grazed ecosystems [e.g., Senft et al., 1985]. Thus we observed the effects of abiotic constraints on plant production as well as land use, potentially feeding back to support less Prosopis biomass in the shallow clay areas. Independent of the actual interacting factors, a combination of abiotic, biotic, and anthropogenic factors have led to distinct, observable differences between the two savanna types.

While the differences between active and dormant fields were obvious from the Landsat NDVI data (Figure 1), important variation did occur within each cover type. In the active fields, plant cover, stand density, and LAI varied significantly.
This may indicate differences in farming practices or species planted; however, even within a single large field (e.g., 10-500 ha), plant cover and spacing were variable (Table 3). Assuming that species composition and treatment were similar within a

Table 2. Foliar. Canopy, and Soil Parameters Retrieved Via Canopy RT Inverse Modeling

\begin{tabular}{|c|c|c|c|c|}
\hline & $\begin{array}{l}\text { Savanna } \\
\text { Mean } \\
\text { (1 s.d.) }\end{array}$ & Min & $\operatorname{Max}$ & $\begin{array}{c}\text { Regional } \\
\text { Mean } \\
\text { (1 s.d.) }\end{array}$ \\
\hline \multicolumn{5}{|c|}{ Tree } \\
\hline $\mathrm{LAI}$ & $2.2(0.4)$ & 0.8 & 2.9 & $3.3(2.2)$ \\
\hline \multicolumn{5}{|l|}{ Leaf Optics } \\
\hline VIS reff* & 0.09 & 0.09 & 0.09 & $0.09(0.00)$ \\
\hline NIR refl & $0.40(0.01)$ & 0.36 & 0.49 & $0.41(0.04)$ \\
\hline VIS trans $\dagger$ & $0.06(0.01)$ & 0.03 & 0.09 & $0.05(0.03)$ \\
\hline NIR trans $\dagger$ & $0.36(0.02)$ & 0.26 & 0.49 & $0.37(0.03)$ \\
\hline soil NIR refl & $0.36(0.06)$ & 0.30 & 0.41 & $0.33(0.08)$ \\
\hline \multicolumn{5}{|c|}{ Herbaceous } \\
\hline LAI & $2.1(0.5)$ & 1.2 & 3.3 & $1.6(1.1)$ \\
\hline \multicolumn{5}{|l|}{ Leaf Optics } \\
\hline VIS reff* & 0.12 & 0.12 & 0.12 & $0.12(0.00)$ \\
\hline NIR refl & $0.36(0.02)$ & 0.32 & 0.43 & $0.39(0.05)$ \\
\hline VIS trans ${ }^{\dagger}$ & $0.08(0.01)$ & 0.04 & 0.10 & $0.07(0.04)$ \\
\hline NIR trans $\dagger$ & $0.39(0.01)$ & 0.25 & 0.48 & $0.40(0.04)$ \\
\hline soil NIR reft & $0.38(0.04)$ & 0.29 & 0.43 & $0.35(0.06)$ \\
\hline
\end{tabular}

Values for Waggoner Ranch are given in columns 1, 2, and 3. Regional mean (1 s.d.) provided in column 4.

*Held constant based on Asner et al. [1998c].

†Linked to NIR reflectance using equations derived by Asner et al. [1998c]. 

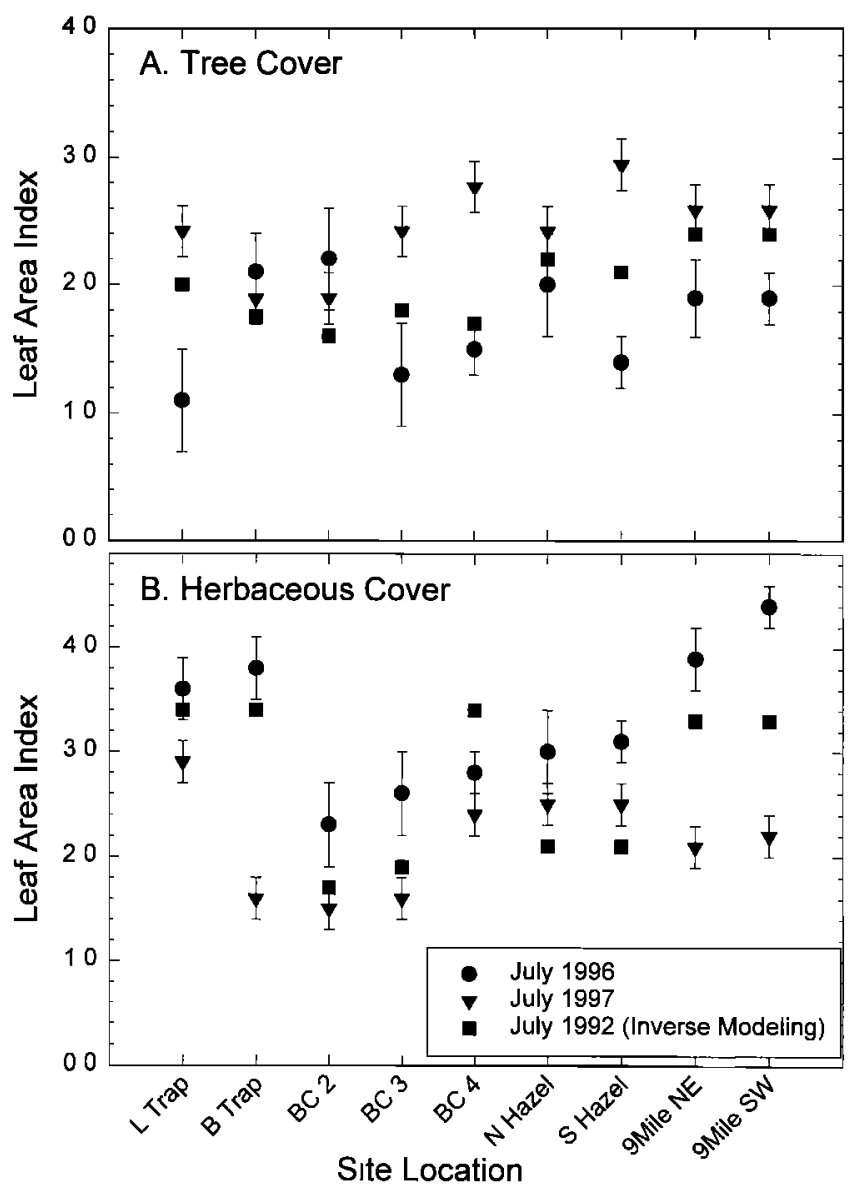

Figure 7. Site comparison of field and inverse modeling LAI estimates. Field LAI values from July 1996 (circles) and 1997 (inverted triangles) are given with error bars $=1$ s.d. LAI values derived via AVHRR inverse modeling in July 1992 (squares) were typically between the wet (1997) and the dry (1996) years. single field, these results could indicate variability in soil properties as observed in the savanna regions.

None of these finer-scale variations in cropping were obvious in the NDVI image (Figure 1). The fusion of multispectral Landsat and multiangle AVHRR data provided more information to discern the details in the land cover features. However, none of these structural analyses provide a direct link to the functional properties of the dominant land cover types. While land cover and land use can be inferred from the suite of structural attributes derived here, the direct link to canopy function is made by convolving structural characteristics (e.g., LAI, stand density, spatial extent) with biophysical properties (e.g., tissue optical properties) to estimate functional attributes such as $\mathrm{C}$ uptake.

\subsection{Regional Carbon Uptake}

Using the parameters derived from the spectral unmixing and inverse modeling analyses, we modeled $\mathrm{C}$ uptake in a 32 $\mathrm{km}^{2}$ area of Waggoner Ranch containing the three dominant landscape types, the shallow clay and clay loam savannas and riparian woodlands. The area coincided with two of the $4 \times 4$ $\mathrm{km}$ AVHRR cells used in deriving LAI. The G-O model inversions had provided estimates of crown dimension ratios and stand density at $28.5 \mathrm{~m}$ spatial resolution (Figure 5), while the canopy RT model inversions provided the coarser-scale estimates of LAI (at $4 \times 4 \mathrm{~km}$, Plate 3 ). Thus LAI was held to a constant value in each of the two AVHRR cells (each contained 19,698 TM pixels). This provided a unique opportunity to isolate the effect of intercanopy shading on ecosystem-level C uptake.

For equation (5), changes in sunlit and shaded cover fractions $\left(K_{l}\right)$ were calculated throughout each day based on the crown dimension ratios $(b: r, h: b)$, stand density $(\lambda)$, and solar geometry at time $(t)$ [Li and Strahler, 1992]. Woody plant and herbaceous canopies were assigned light utilization efficiency factors $(\varepsilon)$ of 0.32 and 0.29 , respectively, which are reasonable values for subtropical savanna vegetation during

Table 3. Summary of Canopy and Landscape Structural Characteristics for Five Dominant Land Cover/Land Use Types in North Texas Study Region

\begin{tabular}{|c|c|c|c|c|c|}
\hline \multirow[b]{2}{*}{ Characteristics } & \multicolumn{2}{|c|}{ Savanna } & \multirow[b]{2}{*}{$\begin{array}{l}\text { Riparian } \\
\text { Woodlands }\end{array}$} & \multicolumn{2}{|c|}{ Agriculture* } \\
\hline & $\begin{array}{l}\text { Clay } \\
\text { Loams }\end{array}$ & $\begin{array}{c}\text { Shallow } \\
\text { Clays }\end{array}$ & & $\begin{array}{l}\text { Actıve } \\
\text { Fields }\end{array}$ & $\begin{array}{l}\text { Dormant } \\
\text { Fields }\end{array}$ \\
\hline Woody plant cover, $\%$ & $31-53$ & $4-24$ & $58-77$ & . & $\cdots$ \\
\hline Herbaceous cover, $\%$ & $33-61$ & $12-27$ & $0-19$ & $52-100$ & $0-18$ \\
\hline Bare soil, \% & $0-16$ & $27-44$ & $1-2$ & $0-48$ & $72-100$ \\
\hline Stand density & $0.04-0.11$ & $0.02-0.05$ & $0.14-0.26$ & $0.75-1.00$ & $0.00-0.01$ \\
\hline $\mathrm{B}: \mathrm{R} \dagger$ & $0.40-0.65$ & $0.31-0.82$ & $0.51-0.79$ & $0.50-0.58$ & $\cdots$ \\
\hline $\mathrm{H}: \mathrm{B} \dagger$ & $1.13-2.53$ & $1.00-2.71$ & $1.30-3.37$ & $1.00-1.32$ & $\ldots$ \\
\hline $\begin{array}{l}\text { Variability of intercanopy } \\
\text { shading, \% }\end{array}$ & $42-62$ & $36-68$ & $34-57$ & $44-55$ & $0-1.1$ \\
\hline Overstory LAI, $\mathrm{m}^{2} \mathrm{~m}^{-2}$ & $1.3-2.9$ & $0.9-1.3$ & $3.2-5.1$ & $2.3-6.0$ & $0.0-1.1$ \\
\hline Understory LAI, $\mathrm{m}^{2} \mathrm{~m}^{-2}$ & $1.6-3.7$ & $0.2-1.8$ & $1.3-2.0$ & 0.0 & 0.0 \\
\hline
\end{tabular}

Cover fractions, tree crown attributes, and shading values were taken from a minimum of 800 Landsat pixels per vegetation type. Canopy LAI estimates were taken from at least three AVHRR pixels containing $>75 \%$ cover of a given vegetation type.

"Within the agricultural fields the "overstory" cover characteristics represent crops. Species composition in these fields were not known at time of satellite overpass.

tCrown dimension ratios; $B: R$ is ratio of vertical to horizontal radıus; $\mathrm{H}: \mathrm{B}$ is ratio of crown height to vertical radius. 


\section{Woody Plants}

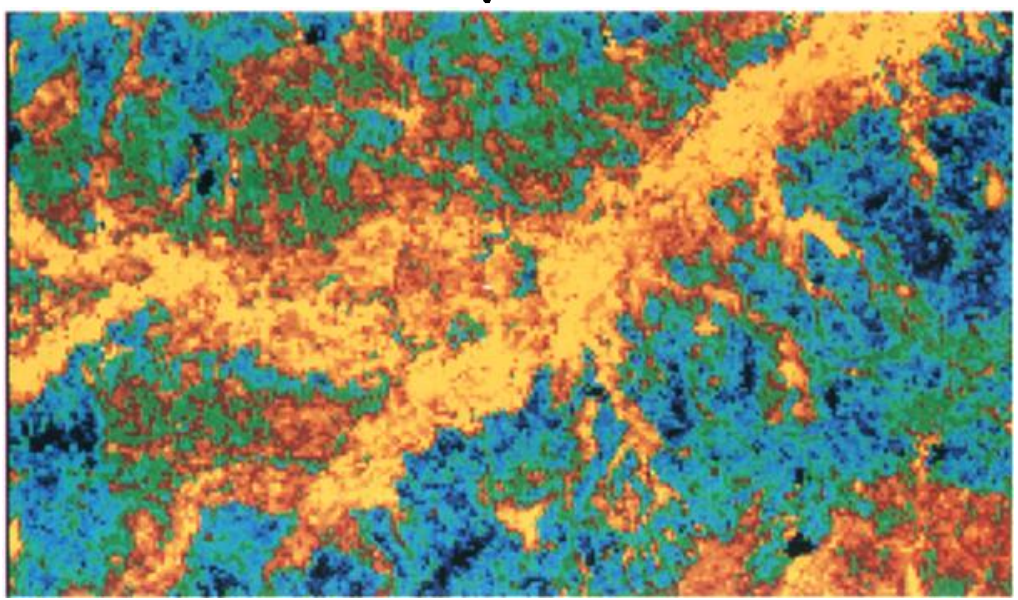

\section{Herbaceous Plants}

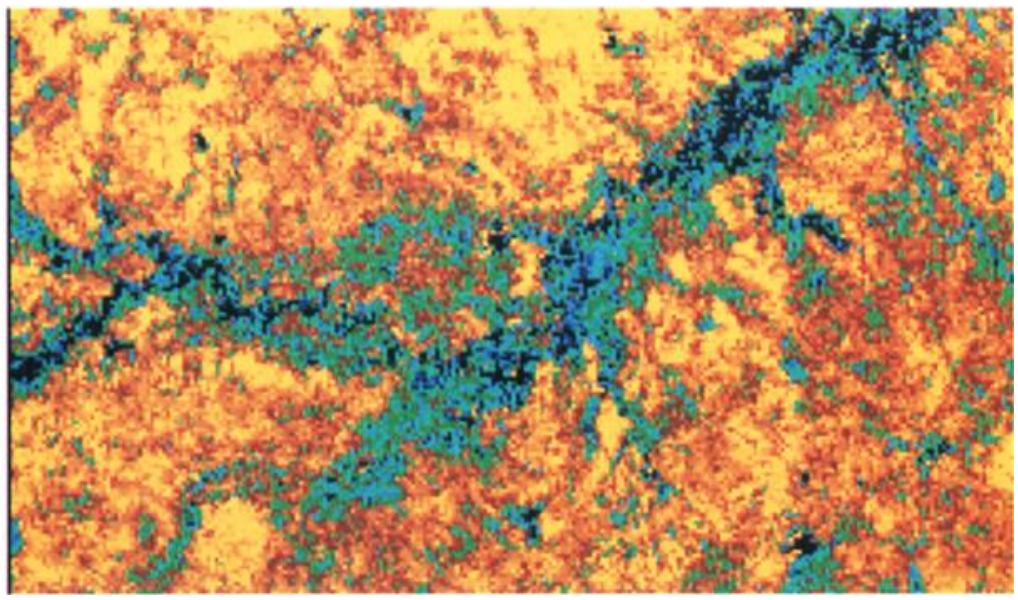

\section{Carbon Uptake}
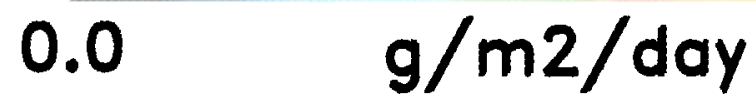

2.8

Plate 4. Regional heterogeneity of daily $\mathrm{C}$ uptake by (a) woody plants and (b) herbaceous canopies. Highest $\mathrm{C}$ uptake was by woody plants in riparian zones, while highest herbaceous $\mathrm{C}$ uptake occurred in the clay loam savannas. Lowest woody plant and herbaceous $\mathrm{C}$ uptake occurred in the shallow clay savannas and riparian woodlands, respectively. 
the peak growing period [Field et al., 1995]. Granted that $\varepsilon$ not only varies with vegetation type and phenology but also with resource availability, they nonetheless provided a means to compare the spatial heterogeneity of daily $\mathrm{C}$ uptake during a July week in this savanna region.

On a per area basis, riparian zones had the highest daily $\mathrm{C}$ uptake by woody plants $\left(1.6-2.8 \mathrm{~g} \mathrm{~m}^{-2}\right)$ and the lowest by herbaceous canopies $\left(0.3-1.1 \mathrm{~g} \mathrm{~m}^{-2}\right)$ (Plate 4). Clay loam savanna areas had higher woody plant $\mathrm{C}$ uptake than the shallow clay savannas $\left(1.8-2.4\right.$ and $0.6-1.1 \mathrm{~g} \mathrm{~m}^{-2}$, respectively; $t$ tests, $p<0.05$ ). Herbaceous $C$ uptake was also significantly higher on the clay loams than on the shallow clays (0.9-1.2 $\mathrm{g}$ $\mathrm{m}^{-2}$ and $0.5-0.9 \mathrm{~g} \mathrm{~m}^{-2}$, respectively; $t$ tests). The relationship between herbaceous $C$ uptake and the spatial density of woody plants was nonlinear (Figure 8a). At low overstory stand density $(\lambda<0.2)$, small increases in $\lambda$ caused significant decreases in herbaceous $\mathrm{C}$ uptake due to intercanopy shading. At higher stand density values $(\lambda>0.2)$, incremental increases in $\lambda$ caused smaller decreases in herbaceous $C$ uptake.

As the stand density of woody plants increased, the per area $\mathrm{C}$ uptake of the overstory increased nonlinearly (Figure 8b). At higher stand density values (riparian woodlands), increases in the number of woody plant crowns resulted in diminished increases in daily $\mathrm{C}$ uptake. Here we resolved the effect of light limitation on plant production. The bifurcation in the relationship in Figure $8 b$ resulted from the different LAI values assigned to trees in each AVHRR grid cell $(4 \times 4 \mathrm{~km}$, or each half of the image in Plate 4). Overstory LAI was estimated at 3.2 in the western cell (left half of Plate 4) and 2.6 in the eastern cell using the RT model inversions. This small difference resulted in the two curves in Figure 8b, both representing riparian woodland vegetation but with slightly different $\mathrm{C}$ uptake values.

These analyses strongly suggest that both canopy structure (LAI) and landscape attributes (primarily vegetation extent and intercanopy shading) drive spatial and temporal variation in PAR absorption and C uptake in savanna ecosystems. While previous studies have focused on the similar role of LAI and vegetation cover in determining PAR absorption and NPP [e.g., Carlson and Ripley, 1997], our analysis emphasizes that other vegetation structural attributes (stand density, dimensions) represent important factors determining functional processes in savannas. Estimates of ecosystem processes in arid and semiarid environments, where high spatial heterogeneity is common, require knowledge of these interacting factors. It is at the landscape level that this structural information has been lacking and is needed to scale ecosystem functional characteristics from leaf to regional levels.

\section{Conclusions}

Remote sensing offers the best available opportunity to observe spatial and temporal variation in ecosystem structure at large scales. The degree to which remote sensing can play a role in biogeochemical research depends on the information extracted from the data and its link to functional variables of interest. Regional-scale biogeochemical analyses necessitate spatially extensive, high-resolution estimates of vegetation characteristics. At the requisite spatial resolution, variation in canopy and landscape structure are observable but also convolved in a highly complex manner. This creates a multivariate situation requiring innovative strategies, multiple data sources,
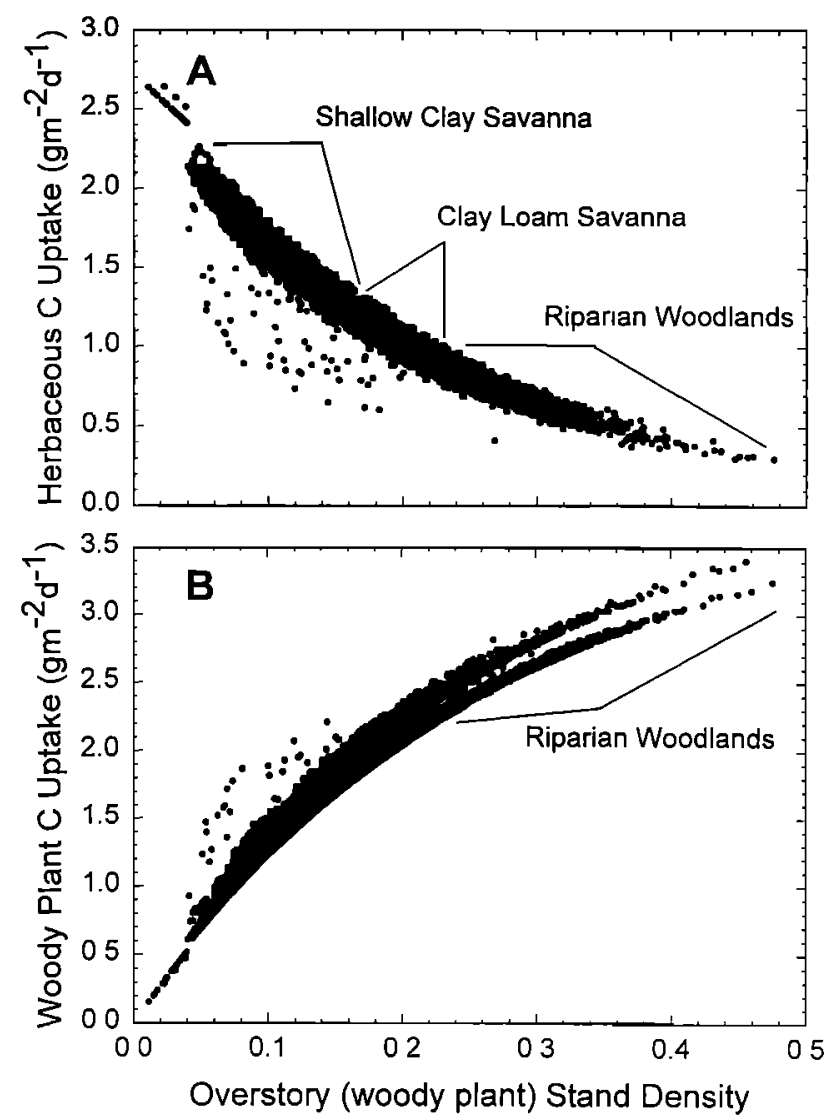

Figure 8. Relationship between stand density of overstory (woody) plants and C uptake. (a) As overstory stand density increased, herbaceous (understory) $\mathrm{C}$ uptake decreased nonlinearly due to intercanopy shading. The three dominant ecosystems found on Waggoner Ranch are delineated. (b) As overstory stand density increased, $C$ uptake increased, but with diminishing returns on a per area basis.

and physically based approaches to access the information most needed for ecological research.

Biophysical scaling approaches provide an avenue to explore the factors controlling the radiative properties of ecosystems and to capitalize on the major sources of variance in remotely sensed data. In this paper, we used a combination of spectral and angular remote sensing data from multiple satellite platforms, along with spectral mixture analysis and inverse modeling, to estimate a suite of canopy and landscape structural variables across diverse land cover types. This approach provided reasonable estimates of vegetation characteristics, allowing further analysis of ecosystem functional attributes such as intercanopy shading, diurnal PAR absorption, and carbon uptake.

The estimated structural parameters emphasized important differences in land cover and land use. Spatial heterogeneity of both abiotic (e.g., soil texture) and anthropogenic (e.g., grazing intensity) factors resulted in observable differences in savanna structure. Localized variation in agricultural areas, both between and within individual fields, was also emphasized in several of the estimated variables. Horizontal and vertical complexity of landscape structure led to measurable differences in the functional attributes of the observed ecosystems. Intercanopy shading drove variation in diurnal foliar-fAPAR at the landscape level, which led to significant differences in estimated carbon uptake. 
As human impacts on the environment continue to increase in extent and intensity, detailed regional level analyses of changing ecosystem structure and function will continue to gain importance. Theoretical and methodological development of strategies to measure, monitor, and understand the role of natural and anthropogenic processes are critically needed to bridge a significant gap between plot level and global-scale analyses. The combination of multisensor data fusion and remote sensing inverse modeling shows promise for making the link between plot and regional scales and between ecosystem structure and function.

Acknowledgments. We thank Jim Ansley and Steve Archer for providing land use information and logistical assistance. We thank Ranga Myneni for providing his radiative transfer code, Xiawen $\mathrm{Li}$ for his geometric-optics code, and Casey Cody for the air photo analysis. David Schimel and Alan Townsend provided critiques of an early version of the manuscript. This work was supported by NASA Innovative Research grant NAGW-4689, NASA Interdisciplinary Science grant NAGW-2662, and NASA Earth System Science fellowship to G.P.A.

\section{References}

Ansley, R. J., D. L. Price, S. L. Dowhower, and D. H. Carlson, Seasonal trends in leaf area of honey mesquite trees: Determination using image analysis, J. Range Manage., 45, 339-344, 1992.

Archer, S., Woody plant encroachment into southwestern grasslands and savannas: Rates, patterns and proximate causes, in Ecological Implications of Livestock Herbivory in the West, edited by M. Vavra, W. A. Laycock, and R. D. Pieper, pp. 13-68, Soc. Range Manage., Denver, Colo., 1994.

Asner, G. P., and C. A. Wessman, Scaling PAR absorption from the leaf to landscape level in spatially heterogeneous ecosystems, Ecol. Model., 101, 396-413, 1997.

Asner, G. P., C. A. Wessman, and J. L. Privette, Unmixing the directional reflectances of AVHRR subpixel land covers, IEEE Trans. Geosci. Remote Sens., 35, 868-878, 1997.

Asner, G. P., B. H. Braswell, D. S. Schimel, and C. A. Wessman, Ecological research needs from multi-angle remote sensing data, Remote Sens. Environ., 63, 155-165, 1998a.

Asner, G. P., C. A. Wessman, and S. Archer, Scale dependence of PAR absorption in terrestrial ecosystems, Ecol. Appl., in press, 1998b.

Asner, G. P., C. A. Wessman, D. S. Schimel, and S. Archer, Variability in leaf and litter optical properties: Implications for BRDF model inversions using AVHRR, MODIS, and MISR, Remote Sens. Environ., 63, 210-226, 1998c.

Asrar, G., R. B. Myneni, and B. J. Choudhury, Spatial heterogeneity in vegetation canopies and remote sensing of absorbed photosynthetically active radiation: A modeling study, Remote Sens. Environ., 41 85-103, 1992.

Baldwin, D., and W. Emery, Spacecraft attitude variations of NOAA-11 inferred from AVHRR imagery, Intl. J. Remote Sens., 16, 531-548, 1995.

Baret, F., and G. Guyot, Potentials and limits of vegetation indices for LAI and APAR assessment, Remote Sens. Environ., 35, 161-170, 1991.

Barnsley, M. J., A. H. Strahler, K. P. Morris, and J. P. Muller, Sampling the surface bidirectional reflectance distribution function, 1 , Evaluation of current and future satellite sensors, Remote Sens. Rev., 8, 271-311, 1994.

Bateson, C. A., and B. Curtiss, A method for manual endmember selection and spectral unmixing, Remote Sensing Environ., 55, 229 $243,1996$.

Bateson, C. A., G. P. Asner, and C. A. Wessman, Incorporating endmember variability in spectral mixture analysis through endmember bundles, Proc. Seventh Ann. Alrborne Earth Sci. Wkshp. 1:43-52, 1998.

Belsky, A. J., R. G. Amundsen, J. M. Duxbury, S. J. Riha, A. R. Ali, and S. M. Mwonga, The effects of trees on their physical, chemical and biological environments in a semi-arıd savanna in Kenya, J. Appl. Ecol., 26, 1005-1024, 1989.
Braswell, B. H., D. S. Schimel, J. L. Privette, B. Moore III, W. J. Emery, E. W. Sulzman, and A. T. Hudak, Extracting ecological and biophysical information from AVHRR optical data: An integrated algorithm based on inverse modeling, J. Geophys. Res., 101, 23,33523,345, 1996.

Carlson, T. N., and D. A. Ripley, On the relation between NDVI, fractional vegetation cover, and leaf area index, Remote Sens. Envlron., 62, 241-252, 1997.

Carreira, J. A., F. X. Niell, and K. Lajtha, Soil nitrogen availability and nitrification in Mediterranean shrublands of varying fire history and successional stage, Brogeochemistry, 26, 189-204, 1994.

Crutzen, P. J., and M. O. Andreae, Biomass burning in the tropics: Impact on atmospheric chemistry and biogeochemical cycles, Science, 250, 1669-1678, 1990.

deWit, C. T., Photosynthesis of Leaf Canopies, Agric. Res. Rep., 663, Pudoc, Wageningen, Netherlands, 1965.

Field, C. B., J. T. Randerson, and C. M. Malmstrom, Global net primary production: Combining ecology and remote sensing, Remote Sens. Environ., 51, 74-88, 1995.

Gamon, J. A., C. B. Field, M. L. Goulden, K. L. Griffin, A. E. Hartley, G. Joel, J. Penuelas, and R. Valentini, Relationships between NDVI, canopy structure, and photosynthesis in three Californian vegetation types, Ecol. Applic., 5, 28-41, 1995.

Gerstl, S.A.W., Physics concepts of optical and radar reflectance signatures: A summary review, Intl. J. Remote Sens., 11, 1109-1117, 1990.

Goel, N. S., Models of vegetation canopy reflectance and their use in estimation of biophysical parameters from reflectance data, Remote Sens. Rev., 4, 1-212, 1988.

Goel, N. S., and R. L. Thompson, Inversion of canopy reflectance models for estimating agronomic variables, V, Estimation of leaf area index and average leaf angle using measured canopy reflectances, Remote Sens. Environ., 16, 69-85, 1984.

Goward, S. N., and K. F. Huemmrich, Vegetation canopy PAR absorptance and the normalized difference vegetation index: An assessment using the SAIL model, Remote Sens. Environ., 39, 119-140, 1992.

Heitschmidt, R. K., D. L. Price, R. A. Gordon, and J. R. Frasure, Short duration grazing at the Texas Experimental Ranch: Effects on aboveground net primary production and seasonal growth dynamics, J. Range Manage., 35, 367-372, 1982.

Heitschmidt, R. K., S. L. Dowhower, and J. W. Walker, 14- vs. 42paddock rotational grazing: Aboveground biomass dynamics, forage production, and harvest efficiency, $J$. Range Manage., 40, 216-223, 1987.

Heitschmidt, R. K., R. D. Schultz, and C. J. Scifres, Herbaceous biomass dynamics and net primary production following chemical control of honey mesquite, $J$. Range Manage., 39, 67-71, 1986.

Huete, A. R., A soil-adjusted vegetation index (SAVI), Remote Sens. Environ., 25, 295-309, 1988.

Kauffman, J. B., D. L. Cummings, and D. E. Ward, Relationships of fire, biomass and nutrient dynamics along a vegetation gradient in the Brazilian Cerrado, J. Ecol., 82, 519-531, 1994.

Knoop, W. T., and B. H. Walker, Interactions of woody and herbaceous vegetation in a southern African savanna, J. Ecol., 73, 235253, 1985.

Kuusk, A., The hot spot effect in plant canopy reflectance, in PhotonVegetation Interactions: Applications in Optical Remote Sensing and Plant Ecology, edited by R. B. Myneni, and J. Ross, pp. 9-44, Springer-Verlag, New York, 1991.

$\mathrm{Li}, \mathrm{X}$., and A. H. Strahler, Geometric-optical modeling of a coniferous forest canopy, IEEE Trans. Geosci. Remote Sens., 23, 207-221, 1985.

$\mathrm{Li}, \mathrm{X}$, and A. H. Strahler, Geometric-optical bidırectional reflectance modeling of the discrete crown vegetation canopy: Effect of crown shape and mutual shadowing, IEEE Trans. Geoscl. Remote Sens., 30, 276-292, 1992.

Matthews, E., Global vegetation and land-use: New high-resolution databases for climate studies, J. Appl. Meteorol., 22, 474-487, 1983.

Myneni, R. B., and G. Asrar, Radiative transfer in three-dimensional atmosphere-vegetation media, J. Quant. Spectrosc. Radiat. Transfer, 49, 585-598, 1993.

Myneni, R. B., J. Ross, and G. Asrar, A review on the theory of photon transport in leaf canopies, Agnc. Forest Meteorol., 45, 1-153, 1989.

Norman, J. M., Scaling processes between leaf and canopy levels, in Scaling Physiological Processes: Leaf to Globe, edited by J. R. Ehleringer, and C. B. Field, Academic, San Diego, Calif., 1993. 
Privette, J. L., R. B. Myneni, C. J. Tucker, and W. J. Emery, Invertibility of a 1-D discrete ordinates canopy reflectance model, Remote Sens. Environ., 48, 89-105, 1994.

Privette, J. L., W. J. Emery, and D. S. Schimel, Inversion of a vegetation reflectance model with NOAA AVHRR data, Remote Sens. Environ., 58, 187-200, 1996.

Randerson, J. T., M. V. Thompson, T. J. Conway, I. Y. Fung, and C. B. Field, The contribution of terrestrial sources and sinks to trends in the seasonal cycle of atmospheric carbon dioxıde, Global Bıogeochem. Cycles, 11, 507-534, 1997

Richards, J. A., Remote Sensing Digutal Image Analysts, SprıngerVerlag, New York, 1993

Rosborough, G. W., D. G. Baldwin, and W. J. Emery, Precise AVHRR navigation, IEEE Trans Geoscı Remote Sens., 32, 644-657, 1994.

Ross, J. K., The Radiation Regime and Archttecture of Plant Stands, Kluwer Acad., Norwell, Mass., 1981.

Ruimy, A., G. Dedieu, and B. Saugier, Methodology for the estimation of terrestrial net primary production from remotely sensed data, $J$. Geophys. Res., 99, 5263-5284, 1994.

Running, S. W., D. L. Peterson, M. A. Spanner, and K. B. Teuber, Remote sensing of coniferous forest leaf area, Ecology, 67, 273-276, 1986.

Scholes, R. J., and S. R. Archer, Tree-grass interactions in savannas, Ann. Rev. Ecol. System., 28, 514-544, 1997.

Sellers, P. J., et al., Modeling the exchange of energy, water, and carbon between continents and the atmosphere, Sclence, 275, 502509, 1997.

Senft, R. L., L. R. Rittenhouse, and R. G. Woodmansee, Factors influencing patterns of cattle grazing behavior on shortgrass steppe, J. Range Manage., 38, 82-87, 1985.

Shugart, H. H., Plant and ecosystem functional types, in Plant Functhonal Types: Their Relevance to Ecosystem Properties and Global Change, edited by T. M. Smith, H. H. Shugart, and F. I. Woodward, pp. 2-46, Cambridge Univ. Press, New York, 1997.

Shultis, J. K., and R. B. Mynenı, Radiative transfer in vegetation canopies with anisotropic scattering, J. Quant Spectrosc. Radiat Transfer, 39, 115-129, 1988.

Stowe, L. L., E. P. McClan, R. Carey, P. Pellegnno, G. Gutman, P. Davis, C. Long, and S. Hart, Global distribution of cloud cover derived from NOAA AVHRR operational satellite data, $A d v$. Space Scl., II, 51-54, 1991.

Tanre, D., B. N. Holben, and Y. J. Kaufman, Atmospheric correction algorithms for NOAA-AVHRR products: Theory and application, IEEE Trans. Geosci. Remote Sens., 30, 231-248, 1992.

Tieszen, L. L., B. C. Reed, N. B. Bliss, B. K. Wylıe, and D. D. DeJong, NDVI, $C_{3}$ and $C_{4}$ production, and distributions in Great Plains grassland land cover classes, Ecol. Appl., 7, 59-78, 1997.

Tothill, J. C., and J. J. Mott, Ecology and Management of the World's Savannas, Aust. Acad. Scl., Canberra, 1985.

Townsend, A. R., B. H. Braswell, E. A. Holland, and J. E. Penner, Spatıal and temporal patterns in terrestrial carbon storage due to depositıon of anthropogenic nitrogen, Ecol. Appl., 6, 806-814, 1996.

van Leeuwen, W.J.D., and A. R. Huete, Effects of standing litter on the biophysical interpretation of plant canopies with spectral indices, Remote Sens. Environ., 55, 123-134, 1996.

Vermote, E. D., and Y. J. Kaufman, Absolute calibration of AVHRR visible and near-infrared channels using ocean and cloud views, Intl. $J$ Remote Sens., 16, 2317-2340, 1995.

Vermote, E., D. Tanre, J. L. Deuze, M. Herman, and J. J. Morcrette, Second Simulation of the Satellite Signal in the Solar Spectrum (6S), 6S User Guide, NASA-Goddard Space Flight Cent., Washıngton, D. C., 1994.

Walker, B. H., Landscape and regional-scale responses of terrestrial ecosystems to global change, Ambio, 23, 67-80, 1994.

Wessman, C. A., and G. P. Asner, Ecosystems and the problems of large-scale measurements, in Successes, Limitations, and Frontiers in Ecosystem Ecology, edited by P. Groffman, and M. Pace, pp. 346371, Springer-Verlag, New York, 1998.

Wessman, C. A., C. A. Bateson, and T. L. Benning, Detecting fire and grazıng patterns in tallgrass prarre using spectral mixture analysis, Ecol. Appl., 7, 493-511, 1997.

G. P. Asner (corresponding author), C. A. Bateson, and C. A. Wessman, CIRES/CSES, Campus Box 216, University of Colorado, Boulder, CO 80309-0216. (e-mail: asner@cses.colorado.edu)

N. El Saleous, Department of Geography, University of Maryland, College Park, MD 20742.

J. L. Privette, NASA Goddard Space Flight Center, Greenbelt, MD 20771.

(Received March 3, 1998; revised July 15, 1998; accepted July 20, 1998.) 